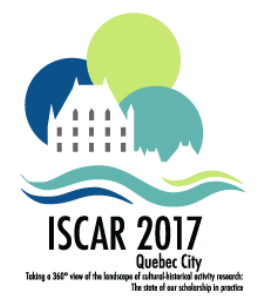

\title{
The Need for Chess in School and Its Role in the Dynamics of Child Development
}

Oksana V. Glukhova

KSUU@INBOX.RU

South Ural State University

Satka, Russia

\begin{abstract}
The article describes the methodology for studying the dynamics of increasing the level of development of intellectual processes in children learning to play chess with the help of the reflective-activity approach. It describes the formation of the mental plan of action and position of agency (subjectness position) in the planning of the student's own developmental trajectory and learning. The results of the influence of chess lessons on the qualitative leap in the development of junior students in comparison with children not engaged in chess are considered. The developing potential of chess lessons for students is also described.
\end{abstract}

Keywords : Intellectual processes; Cognitive processes: memory (visual-mediated and auditory); Attention; Working capacity; Ability to think logically on the verbal and nonverbal level; Ability to plan and predict the results of actions; Psychological research; Chess for the overall development; Mental plan of action; Position of agency (subjectness position); Zone of proximal development; Reflective-activity approach. 
Today in Russia there is a statement that our educational system should work ahead of time in order to prepare a person for life in a changing environment. The new quality of education should be aimed at increasing the intellectual potential of future graduates, understanding their abilities and understanding the need to make the right decisions in conditions of uncertainty.

These are qualities of personality that consistent with the demand of modern reality for a successful person. And they develop in the process of acquaintance and understanding in the future the philosophy of playing chess.

In the small city Satka in the Chelyabinsk region, the chess projects are supervised by the collective of the chess club "Vertical". In the training of young chess players, as well as in the creation of a base for the overall development of young students, a significant role is played by the project "Chess for overall Development", which started in the autumn of 2004 (Zaretskii, Gordon, \& Glukhova, 2011).

The program for learning chess was developed under the guidance of Viktor Zaretskii, candidate of psychological sciences, professor of the department of individual and group psychotherapy of the psychological counseling department of the Moscow State Psychological and Pedagogical University.

Teaching children the basics of the game and using chess as a tool for their overall development was carried out by school teachers, based on the development of the ability to act in the mind, on the use of the reflective-activity approach in the lessons, and on the application of the theory of Lev Vygotskii about the zone of the nearest development of the child (Vygotsky, 1984; Zaretskii, 2008b).

In the framework of this project, the lesson was built in such a way that each student had to face the task that he himself could not fulfill. In scientific terms, each student had to enter his zone of proximal development. As a result, everyone began to move at their own individual pace. The task of an adult is to catch this pace and organize for the child exactly the activity that will be useful at the moment (Zaretskii, 2008a).

Orientation to the joint work of the teacher and student in building the trajectory of his development, as well as the child's readiness to reflect on his successes and failures, created the basis for the dynamics of cognitive processes in all children participating in the project to be positive.

When planning and implementing a chess project, an important role was assigned to psychological and diagnostic support.

The selection of methods for conducting comparative cut-off diagnostics was carried out by the specialists of the Moscow State Psychological and Pedagogical University Svetlana Volikova, and Alla Kholmogorova. The research was conducted by psychologists of schools in the Satka district together with specialists from Moscow. 
A package of psychological methods that tested the basic cognitive processes of the child was selected. While compiling this package, we tried to cover almost all the basic cognitive processes of the child: memory (visual mediated and aural), attention, performance, the ability to think logically on a verbal and non-verbal level, the ability to plan and predict the results of actions. These cognitive processes are involved in the successful learning of a child.

It is noteworthy that the main goal of the project "Chess for overall development" was the idea of creating a methodology for making classes that would allow children in the process of playing chess to develop their intellectual and personal potential:

- analyze the situation on the chessboard mentally, i.e. act in the mind;

- comprehend own activity in order to beat the opponent;

- independently make decisions in necessity to make the next move;

- plan own activity in accordance with the current situation on the board;

- concentrate and allocate attention to the course of the game, the opponent's strategy and own position;

- train the memory in a situation when it is necessary to repeat chess technique.

Therefore, our selection of methods allows us to fix the specifics of the influence of the chess program on the development of the child.

1. Method "Remembering 10 words" (author - Dr. AN Leontiev). The method is aimed at identifying the features of direct memorization. The technique allows to reveal the amount of memory and the ability to memorize mechanically, i.e. how many times the child needs to repeat a set of words so that he will remember them.

2. Method "Determining the level of development of visual mediated memory" (author - P. Ya. Kees, adapted by A. G. Liders, V. G. Kolesnikov). The method makes it possible to understand at what level the child's ability to remember the information perceived by him is formed, and whether he can use logical "helpers" when memorizing.

In the fourth grade, this method was not carried out.

3. The method of "simple analogies" - for 2-3 classes. For 4 classes, subtest $6 \mathrm{~A}$ is presented from the GIT methods (group intellectual test).

The method is aimed at identifying the features of the development of the verbal intelligence of the child, his ability to establish verbal and logical connections. 
4. Test "Progressive matrices of Raven".

This test identifies the level and characteristics of the development of formal (nonverbal) intelligence. Shows the child's ability to establish formal logical connections. In this study, it is used to diagnose students of the 2nd and 3rd grade. To study the features of the nonverbal intelligence of students of the 4th grade, the subtest 5A of the GIT methodology was used.

5. Method "Determination of the level of the formation of the internal plan of action":

- $1^{\text {st }}$ variant - author - P. Ya. Keas, adapted by A. G. Liders, V. G. Kolesnikov. It is used for diagnosing students of primary school.

- For the diagnosis of students of the 4th grade, the subtest 7A of the Intellectual Test, developed by Amthauer, was applied.

- 2nd version - modification of the game for the development of attention (proposed by A. B. Kholmogorova).

The method shows how the child has developed the ability to think and plan certain actions for several moves forward.

6. Method "Correction test Bourdon".

It is aimed at revealing features of the child's attention and its performance.

This package has proved itself well throughout the study.

The received data were processed using the statistical software package SPSS for Windows, Standard Version 11.5, Copyright @ C SPS Inc., 2002, most often in the international practice used for statistical analysis of the results of psychological research.

In order to identify the specific impact of lessons in the chess project on the development of children, a comparative analysis method was used. We compared the dynamics of changes in the level of development of cognitive processes in three large groups of students. The first included students who are engaged in chess on the project (the main group is the "chess project"). The students of the second group studied chess according to the program of Igor Sukhin (the comparison group is "chess universal"). The third group consisted of children not engaged in chess (the control group was "without chess").

The selection of the experimental class and comparison classes took into account the socio-demographic data, indicators of overall development and qualifications of teachers (all teachers had the first qualification category at the time of the research).

Socio-demographic data of the class were obtained with the help of teachers' answers to the questions of the questionnaire on the composition and well-being of families of students. The researched groups were roughly leveled up in order to be able to assert that the differences in the dynamics of development may be attributed to the difference in the learning process of these students. 
In total, since 2004 to 2017 , about 870 students of grades $1-9$ of secondary schools in the city of Satka (schools No. 1, 5, 12, 13, 14 and 40) took part in the longitudinal study.

In the study of the initial stage of the analysis of the influence of chess lessons on the development of students (2004-2008), all classes in the primary school took part.

An analysis of the results obtained made it possible to draw conclusions that according to the positive dynamics of the development of cognitive processes in the academic year, the students of the class on which the experiment was conducted outstripped all the comparison groups. During the designated time (the first year of the project), the students of the experimental group improved their results for seven indicators (see Table 1). Their visual and aural memory improved, they began to cope with tasks for non-verbal thinking better, they became more attentive, performed, more able to plan their actions in the mind (this is confirmed by the basic and additional methods to identify the internal plan of action). Negative dynamics for any indicator was not found. Such bright indicators of dynamics were not found in any of the comparison groups.

Table 1

Comparison of the level of development of cognitive processes of students of grade 2 of school No. 14 (main group) for the period from September 2004 to May 2005 (the first year in the project)

\begin{tabular}{|c|c|c|c|}
\hline \multirow[b]{2}{*}{ Indicator } & \multicolumn{3}{|c|}{ Time of the research } \\
\hline & $\begin{array}{l}\text { September } \\
(N=24, M(S D))\end{array}$ & $\begin{array}{l}\text { May } \\
(N=24, M(S D))\end{array}$ & $\begin{array}{l}\text { Significance } \\
\text { level }(p)\end{array}$ \\
\hline 1. Memory & $5.4(1.9)$ & $9.0(1.4)$ & $0.000^{* *}$ \\
\hline 2. Visual memory & $8.6(1.8)$ & $9.2(2.3)$ & $0.000 * *$ \\
\hline 3. Nonverbal intelligence & $6.2(2.7)$ & $7.9(3.0)$ & $0.057 t$ \\
\hline 4. Attention & $0.77(0.3)$ & $0.9(0.1)$ & $0.003^{*}$ \\
\hline 5. Performance & $178.8(82.7)$ & $288.7(66.5)$ & $0.000^{* *}$ \\
\hline 6. Ability to act in the mind 1 & $1.4(1.5)$ & $2.8(1.6)$ & $0.000 * *$ \\
\hline 7. Ability to act in the mind 2 & $2.5(0.66)$ & $2.8(0.4)$ & 0.048 \\
\hline \multicolumn{4}{|l|}{$M$ - average value } \\
\hline \multicolumn{4}{|l|}{$S D$-Standard deviation } \\
\hline \multicolumn{4}{|c|}{ * - significance level $p<0.05$ (Mann — Whitney U-test) } \\
\hline \multicolumn{4}{|c|}{${ }^{* *}$ - significance level $p<0.001$ (Mann — Whitney U-test) } \\
\hline \multicolumn{4}{|l|}{$t$ - significance as tendency } \\
\hline
\end{tabular}

To the studies organized in the period from 2008 to 2010, students of the first - fourth grades were involved. Dynamics of development of children learning chess within the framework of the Chess for Overall Development project has also been shown to be consistently positive.

The task of the new stage of diagnostics (2010-2013) was the study of a combined primary class in composition, which, in addition to the basic composition of the children, included students with disabilities. The diagnostic section (2010-2012) to determine the 
dynamics of development of children with disabilities (mental retardation) also confirmed the positive effect of chess (see Table 2).

Table 2

Comparison of the level of development of cognitive processes of students of grade 2 of school No. 13 (main group) for the period from May 2011 to May 2012

\begin{tabular}{llll}
\hline & \multicolumn{3}{c}{ Time of the research } \\
\cline { 2 - 4 } Indicator & $\begin{array}{l}\text { May 2011 } \\
(N=26, M(S D))\end{array}$ & $\begin{array}{l}\text { May 2012 } \\
(N=26, M(S D))\end{array}$ & $\begin{array}{l}\text { Significance } \\
\text { level }(p)\end{array}$ \\
\hline 1. Memory & $5.56(2.36)$ & $\mathbf{8 . 6 ( 1 . 1 5 )}$ & $\mathbf{0 . 0 0 0 * *}$ \\
2. Visual memory & $4.52(2.68)$ & $\mathbf{6 . 3 0 ( 1 . 8 9 )}$ & $\mathbf{0 . 0 0 3}^{*}$ \\
3. Verbal intelligence & $7.32(2.36)$ & $7.78(3.90)$ & 0.663 \\
4. Nonverbal intelligence & $7(1.26)$ & $\mathbf{7 . 9 1 ( 1 . 4 4 )}$ & $\mathbf{0 . 0 1 7}$ \\
5. Attention & $0.81(0.16)$ & $0.86(0.09)$ & 0.191 \\
6. Performance & $188.54(55.90)$ & $\mathbf{2 4 4 . 8 7 ( 8 3 . 1 4 )}$ & $\mathbf{0 . 0 0 2}$ \\
7. Ability to act in the mind 1 & $1.28(0.89)$ & $\mathbf{2 . 1 3}(\mathbf{0 . 8 7})$ & $\mathbf{0 . 0 0 2}$ \\
8. Ability to act in the mind 2 & $2.04(0.46)$ & $\mathbf{2 . 4 6}(\mathbf{0 . 6 4 )}$ & $\mathbf{0 . 0 0 8}$ \\
\hline$M-$ average value & & & \\
$S D$ - Standard deviation & & & \\
$*$ * significance level $p<0.05$ (Mann - Whitney U-test) & & \\
$* *$ - significance level $p<0.001$ (Mann - Whitney U-test) & &
\end{tabular}

The results of the research conducted in May 2012 showed that the second-graders of the main group have a positive dynamic in the development of memory (aural and visual), nonverbal intelligence, performance and the ability to plan actions in the mind. There are statistically significant differences between the May 2011 research and the 2012 research.

Comparison group - second-graders included as a control group - "without chess", improved their results only in three indicators (visual memory, performance and ability to act in the mind (Vygotsky, 1984) (see Table 3).

However, the level of statistical differences is lower than that recorded in the indicators of students in the experimental group. The indicators of the dynamics of intellectual processes are also lower (three against six).

At the same time (2010-2013), an analysis of the level of development of intellectual processes among the first participants of our project and the comparison groups was made. In 2011-2012, these children were studying in the ninth grade, and many of them planned their future professional education outside the school's walls. Therefore, it was so important to trace the existing trends in the development of the entire class as a whole.

For the designated time, a large number of students studying and not studying chess as a whole have increased their level of development of cognitive processes. However, the 
Table 3

Comparison of the level of development of cognitive processes in the 2 nd grade pupils of school \# 40 (without chess) for the period from May 2011 to May 2012

\begin{tabular}{llll}
\hline & \multicolumn{3}{c}{ Time of the research } \\
\cline { 2 - 4 } Indicator & $\begin{array}{l}\text { May 2011 } \\
(N=27, M(S D))\end{array}$ & $\begin{array}{l}\text { May 2012 } \\
(N=25, M(S D))\end{array}$ & $\begin{array}{l}\text { Significance } \\
\text { level }(p)\end{array}$ \\
\hline 1. Memory & $7.6(1.78)$ & $7.9(1.2)$ & 0.709 \\
2. Visual memory & $7.8(2.6)$ & $\mathbf{9 . 4}(\mathbf{1 . 7 )}$ & $\mathbf{0 . 0 0 0}$ \\
3. Nonverbal intelligence & $6.6(2.3)$ & $6.9(2.4)$ & 0.691 \\
4. Attention & $0.89(0.09)$ & $0.7(0.1)$ & 0.264 \\
5. Performance & $173.53(37.22)$ & $\mathbf{2 6 8 . 4 ( 4 8 . 2 )}$ & $\mathbf{0 . 0 0 0}$ \\
6. Ability to act in the mind 1 & $1.25(1.09)$ & $\mathbf{2 . 0 ( 1 . 1 )}$ & $\mathbf{0 . 0 0 2}$ \\
7. Ability to act in the mind 2 & $2.07(0.8)$ & $2.4(0.8)$ & 0.088 \\
\hline$M$ - average value & & & \\
$S D$ - Standard deviation & & & \\
$*$ - significance level $p<0.05$ (Mann - Whitney U-test) & & \\
$* *$ - significance level $p<0.001$ (Mann - Whitney U-test) & &
\end{tabular}

pupils of the experimental classes compared with the background ones have consistently improved their results for more intellectual indicators.

The obtained results again bring us back to the conviction that the stable improvement in the indicators in the experimental classes was promoted by the use of such a method of teaching chess, in which the student in each lesson independently planned actions to overcome yesterday's difficulties and could deliberately reflect on the motives for his training. As a result, the intellectual and personal qualities developed, the dynamics of which were initiated by chess lessons.

The words of participants of this project, today's university students, can serve as an illustration of these statements. Future doctor-rehabilitologist Nastia T .: "Chess helped in that, carrying out any task, I, in my mind, represented a plan of action, different options for implementation and possible outcomes. Then I chose the most correct one. This helps to avoid unnecessary mistakes".

Future engineer-mechanic Vasya V.: "Chess helped me to assess the current situation and to consider my further actions. This helps in solving various problems".

The future specialist in artistic metalworking: "Due to the fact that we were trained with the help of a reflective-activity approach, we are more broadly conceived". The opinion of these students of the experimental class, who have grown up, is especially valuable for us, because the goals we set for ourselves at the beginning of the project were achieved by us. Their statements are an additional confirmation. 
Thus, it can be said that the students of the $1^{\text {st }}$ and the $9^{\text {th }}$ grades who study chess within the framework of the project find a positive dynamic of the development of cognitive functions for a larger number of indicators than children not engaged in chess.

In 2014, students in the experimental class finished high school with an impressive result: out of 24 students 18 graduated with five gold medals. This was the best result in the city of Satka, and the Chelyabinsk region.

The current stage of the study (2015-2017) is devoted to the study of the influence of methodological developments on the materials of the methodology on the dynamics of increasing the level of development of intellectual processes in children of comparison groups.

The work on the analysis of all diagnostic results continues and will be presented in our next publications.

I would like to emphasize once again that the results described were obtained over several years of research repeated when testing several classes, which may indicate not only the repeatability, but also the reproducibility of the results. And this, in turn, speaks about the reliability of the conclusions of this psychological research.

\section{References}

Vygotsky, L. S. (1984). Collected works in 6 volumes. Vol. 4. Moscow: Pedagogika.

Zaretskii, V. K. (2008a). Evristicheskiy potentsial ponyatiya «zona blizhayshego razvitiya» [Heuristic potential of concept of ZDP]. Voprosyi psihologii [Questions of psychology], 6.

Zaretskii, V. K. (2008b). Refleksivno-deyatelnostnyiy podhod v rabote s detmi, imeyuschimi trudnosti v obuchenii [Reflective-activity approach in the work with children with learning difficulties]. In Pedagogicheskaya psihologiya [pedagogical psychology]. Moscow: TTs Sfera.

Zaretskii, V. K., Gordon, M. M., \& Glukhova, O. V. (2011). Shahmatyi dlya obschego razvitiya [Chess for overall development], Materialyi mezhdunarodnoy nauchno-prakticheskoy konferentsii. psihologo-pedagogicheskie i mediko-biologicheskie problemyi fizicheskoy kulturyi, sporta, turizma i olimpizma: innovatsii i perspektivyi razvitiya [Materials from international science conference. Psychological and educational, medical and biological problems of physical education, sports, tourism, mountaineering: innovations and trends of development]. Chelyabinsk: Izdatelskiy tsentr YuUrGU. 